\title{
○特集 細胞内膜系の諸相
}

\section{カベオラと形質膜の機能ドメイン}

\section{藤本豊士·野村隆士·青木武生 · 向後 寛}

\section{群馬大学医学部解剖学第一講座 函 371-8511 前橋市昭和町 3-39-22}

\section{Caveolae and Functional Domains of the Plasma Membrane}

\author{
Toyoshi Fujimoto, Ryuji Nomura, Takeo Aoki, and Hiroshi Kogo \\ Department of Anatomy and Cell Biology, \\ Gunma University School of Medicine \\ 3-39-22 Showa-machi, Maebashi, Gunma, 371-8511, Japan
}

\begin{abstract}
Caveolae and rafts are two different domains of the plasma membrane. Caveolae are small invaginations and characterized by the presence of unique membrane proteins named caveolins. Caveolins bind cholesterol, form oligomers, interact with various signaling molecules, and induce caveolae formation. On the other hand, rafts are highly dynamic structure and do not take any characteristic shape; but both caveolae and rafts are enriched with sphingolipids and cholesterol and appear to contain many molecules in common. Some of the functions which have been ascribed to caveolae, such as signal transduction, may be mediated by both caveolae and rafts. Caveolins are thought to be involved in the intracellular cholesterol transport, and an increase or decrease of cholesterol content appears to affect caveolae and rafts. Mutation of caveolin genes or quantitational change of caveolae and caveolins has been reported to occur in several diseases. Further studies should elucidate the physiological roles as well as pathological changes of these functional domains in the plasma membrane.
\end{abstract}

Key words : plasma membrane/caveolae/raft/caveolin

\section{1.はじめに}

細胞表面の小さな陥凹にカべオラ (Caveolae) の名が与えられたのは既に 40 年以上前のことで ある ${ }^{1)}$ (Fig. 1). しかしこの名は長く休眠状態に あり, 内皮細胞などではこれに代わって形質膜小
胞という名称が一般的に用いられてきた. カべオ ラが長い眠りから醒めて一躍脚光を浴びるように なったのはカべオリンの存在が報告されて以後の ことである. 本稿ではカベオラとカベオリン，そ してもう 1 つ重要な形質膜ドメインであるラフ トについて概説したい. 


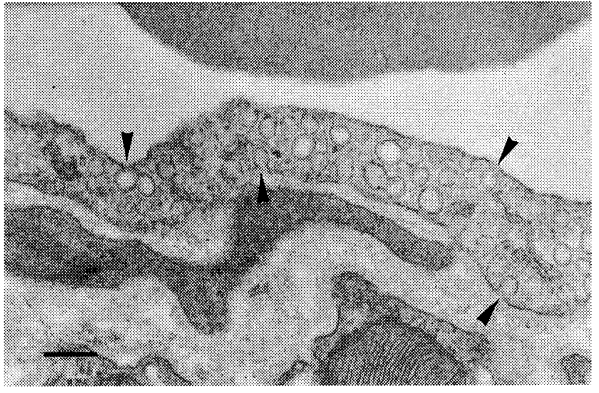

Fig. 1 Electron micrograph of caveolae Many caveolae are observed on the endothelial cell surface (arrowheads). They have been also termed as plasmalemmal vesicles. Bar : $200 \mathrm{~nm}$.

\section{2. カベオリン}

カベオリンはカベオラを特徴づける内在性膜蛋 白質であり，3つの遺伝子でコードされるカべオ リン-1, 2, 3 が同定されている ${ }^{2 \sim 4)}$. カベオリン1,2 は多くの細胞に存在するが, カベオリン -3 の 発現は骨格筋, 心筋などに限られる. カベオリン とカベオラは白色脂肪細胞，血管内皮細胞，平滑 筋細胞などに多く，リンパ球にはない，神経細胞 にはカベオリンがないと考えられていたが，後根 神経節細胞などでは強い発現があることが報告さ れた ${ }^{5)}$.また，カベオリン分子が発現していない にもかかわらず，カベオラ様の構造が観察される 細胞もあり，未知のカベオリン分子が存在する可 能性が示唆されている.

カベオリン $-1,2,3$ の SDS-PAGE 上の分子量 は 20〜22 kD で，共通した高次構造をとると推 測されている ${ }^{6)}$ 。 N , C 両末端は親水性が強く, 中央から $\mathrm{C}$ 末に近い側にはアミノ酸 33 個の疎水 性部分がある. C末のシステイン残基にはパルミ チン酸が結合する ${ }^{7)}$. カベオリン分子は両末端と も細胞質側にあり，細胞外には露出しない (Fig. 2). カベオリン -1 は v-Src 発現細胞で強くチロシ ン燐酸化を受( ${ }^{8)}$, 正常細胞でもチロシン燐酸化 が認められる9.10).

カベオリン-1 は試験管内でホモ・オリゴマー を形成し ${ }^{11)}$ ，カベオリン-3にも同様の性質があ る.オリゴマーの形成には，カベオリンの $\mathrm{N}$ 末

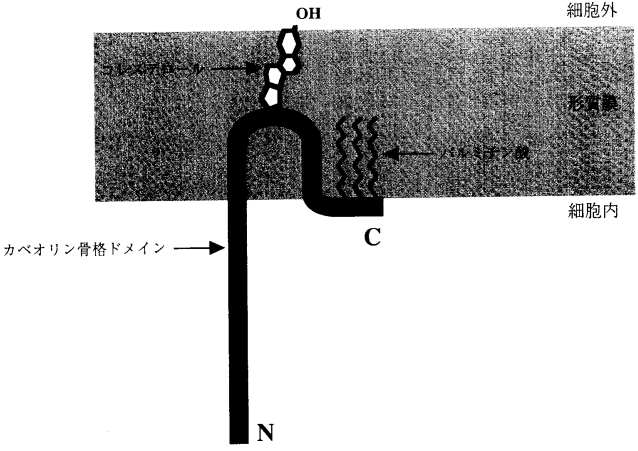

Fig. 2 Putative structure of caveolin-1 Caveolin-1 exposes both $\mathrm{N}$ and $\mathrm{C}$ termini to the cytoplasmic surface, and is bent in the hydrophobic segment in the lipid bilayer. It binds at least one cholesterol molecule, and three palmitoyl residues are attached to the $\mathrm{C}$ terminus. Caveolin-2 and caveolin-3 are thought to take a similar structure.

親水性部分のうち, 形質膜に埋まる直前の部分 (七 トカベオリン-1 ではアミノ酸 61〜101 に相当す る）が必要である，細胞内の合成過程では，粗面 小胞体において分子量 $200 \sim 400 \mathrm{kD}$ のオリゴ マーが形成され，ゴルジ装置でオリゴマー同士が 会合してさらに大きな複合体を作ると考えられて いる.ゴルジ装置での現象にはカベオリンの $\mathrm{C}$ 末 部分が関与する ${ }^{12)}$. カベオリン・オリゴマーは カベオラの陥凹構造形成に必要であり, カベオリ ンおよびカべオラを欠如するリンパ球にカベオリ ン-1 をトランスフェクトするとカベオラが形成 される ${ }^{13)}$.しかし，カベオリン発現量とカベオ ラ数が相関しない場合もあり ${ }^{14)}$ ，他の因子，亡 くにコレステロールなどの脂質の関与が重要であ ると考えられている.

カベオリン-1 のアミノ酸 82〜101 の部分はカ ベオリン骨格ドメイン caveolin-scaffolding domain と名付けられ, G $\alpha$, Src, eNOS, Ha-Ras などにある共通のモチーフと結合する性質をも $つ^{15)}$.これらの分子は不活性状態にあるときに カベオリン-1 との親和性がより強く, またカべオ リン-1 骨格ドメインのペプチドによって活性を 抑制される，すなわち，カベオリンは多くのシグ ナル伝達関連分子に結合するだけでなく，それら 
Table 1. Molecules reported to be enriched in caveolae or caveolae-like domains

GTP-binding proteins : Gi $\alpha$, Gs $\alpha$, G $\beta$, Rab5, Rap1, Ras

Kinases and phosphatases: $\quad$ Src, Yes, Lyn, Fyn, Lck, Fgr, Nck (p59), JAK-2, PKC $\alpha$, PKC $\beta$, Casein kinase II, MAP kinase, PI3-kinase, Raf1, Syp, PTP-1D

Signaling molecules : $\quad$ Shc, Grb 2, Nck, mSos-1, 14-3-3, vav, PLC $\gamma$, eNOS

Cytoskeletal proteins : $\quad$ Actin, Myosin II, Gelsolin, Dystrophin, $\alpha$-Sarcoglycan, $\beta$-Dystroglycan, Annexin II, Annexin VI

Receptors, channels, pumps : Muscarinic acetylcholine receptor, Endothelin receptor type A Bradykinin receptor, u-PA receptor, EGF receptor, PDGF receptor, Insulin receptor, Atrial natriuretic peptide receptor,RAGE, CD36, SR-B1, p75NTR, $\mathrm{Ca}^{2+}$ sensing receptor, Porin, Aquaporin-1, IP3 receptor, $\mathrm{Ca}^{2+}$ pump

Other proteins : GPI-linked proteins (including PrPc, PrPsc, folate receptor) VAMP, SNARE, NSF, Duffy antigen, Atrial natriuretic peptide, Hyaluronan, Tissue Factor, Axonal amyloid precursor protein, Flotillin, Epidermal surface antigen

Lipids Sphingomyelin, Ceramide, Ganglioside GM1, Other glycolipids

の機能制御にも関与すると考えられている. G $\alpha$ を例に取るとカベオリン-1 は GDP 結合型の G $\alpha$ と結合して, GDP 解離抑制蛋白質 (GDI) の作 用を示す.一方, カベオリン-2 にもカベオリン -1 と同様のドメインがあり, G $\alpha$ に対して GTPase 活性促進蛋白質 (GAP) として作用する ${ }^{16)}$. 従って, カベオラにはカベオリン $-1,2$ と結合し た不活性型の $\mathrm{G} \alpha$ が存在すると推測される. カべ オリン骨格ドメインには PDGF やエンドセリン の受容体, プロテインキナーゼ C なども同様に 結合するらしい. カベオリンを介する結合によっ て効率的なシグナル伝達が可能になり, 異なる伝 達経路間のクロストークの促進や抑制が行われる と考えられている.

\section{3. カベオラとラフト}

細胞を Triton X-100 よ゙の界面活性剂で処理 し, 不溶性の成分を密度勾配遠心法で分画すると, 糖脂質やコレステロールに富む浮遊性画分 (Triton-insoluble floating fraction : TIFF) が得 られる ${ }^{17)}$. TIFFは形態的には大小さまざまな小 胞であり, 出発材料である細胞と比較して, カべ オリンが数百倍濃縮される. 当初, TIFF は精製 されたカべオラそのものではないかと考えられ た ${ }^{18)}$. しかし, カベオリンやカベオラのない細 胞からも TIFF が得られ, カベオラのある細胞
から得られた TIFF と同様の成分が含まれてい ること ${ }^{19.20)}$ ，またTIFFに濃縮される分子の 中には免疫組織化学的にカベオラに集中していな いものがあること21，22)，などが明らかになった。 現在では, TIFF はカベオラのほかにラフトや一 部の細胞内膜系の成分を含み, 界面活性剂の作用 により人工的に小胞を形成したものと考えられて いる.

TIFF 以外にもカべオラを精製するための方法 が報告されている $23 \sim 25)$. 多くの方法の共通点 は, まずカべオラをカべオラ以外の形質膜から切 り離すためにアルカリや界面活性剂などの化学的 処理あるいは超音波やピペッティングなどの機械 的処理を行い，ついで密度勾配遠心法で低密度の 部分に浮遊してくる画分を採取することである.

Table 1 はこれらの方法によって得られた「カべ オラ画分」に濃縮している分子のリストで, 多く の受容体やシグナル伝達関連分子などが含まれて いる.ただし，この中にはカべオラのない細胞か ら得た TIFF への濃縮を根拠にして，「カべオラ 様ドメインに局在する」と報告されたものが含ま れる. カべオラ精製のいずれの方法においてもカ ベオリンが濃縮されることは確かであるが, カベ オラ以外の成分, とくに後に述べるラフト成分の 混入がないことの証明は難しい，つまりカベオリ ンがカベオラの明確なマーカーたり得るのに対 し，ラフトのマーカーとなる分子は確定していな 


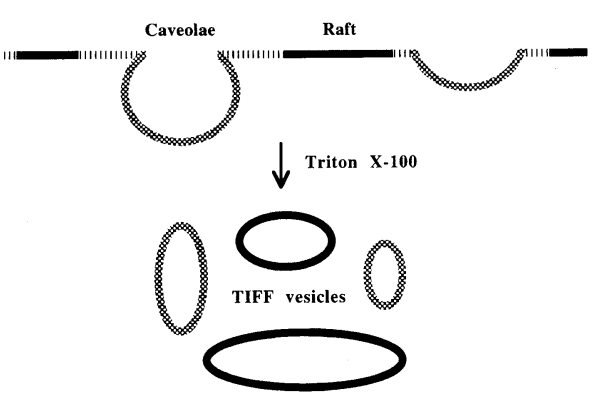

Fig. 3 Caveolae and rafts

Caveolae contain caveolins and assume an invaginated shape of uniform diameter (50 80 $\mathrm{nm}$ ), while rafts are thought to be dynamic domains changing size and shape continuously. Detergents like Triton X-100 dissolve the plasma membrane areas outside of caveolae and rafts, and thus insoluble caveolae and rafts are thought to fuse each other and form vesicles of various diameter.

い. Table 1 の分子の多くが，抗カベオリン抗体 とのアフィニティーによって得られた画分には濃 縮されなかった，という結果は示唆的である ${ }^{26)}$. 個々の分子がカべオラに集中しているかどうかを 決定するためには，少なくとも複数の異なる原理 に基づく方法で確かめることが必要であろう。こ の観点から見直すと, Table 1 の分子のうち, 確 実にカベオラのみに集中していると結論できるも のは多くない.カルシウムに関連する分子群 $\left(\mathrm{IP}_{3}\right.$ リセプター様蛋白質 ${ }^{27,28)}$, カルシウムポン プ28.29), $\mathrm{eNOS}^{30 \sim 32)}$ ) はその中に属し, 筆者 らはカルシウムに関する機能をカべオラ固有のも のであると考えている ${ }^{33)}$.

ラフトはスフィンゴ脂質とコレステロールに富 む膜ドメインとして提唱され，頂部形質膜へ向か う蛋白質のソーティングと小胞輸送に関与すると 考えられてきた ${ }^{34)}$. グリセロ燐脂質に比較する と, スフィンゴ糖脂質やスフィンゴミエリンは(1) 相転移温度が高い，(2)アシル鎖が長い，(3)不飽和 脂肪酸の割合が少ないなどの特徴がある，スフィ ンゴ脂質が密にパックされ，その間にコレステ ロールが入り込むことによってラフトが形成され ると推測されている. ラフトの実態を捉えること は困難であったが, 最近になって $2 つ の$ 新たな方

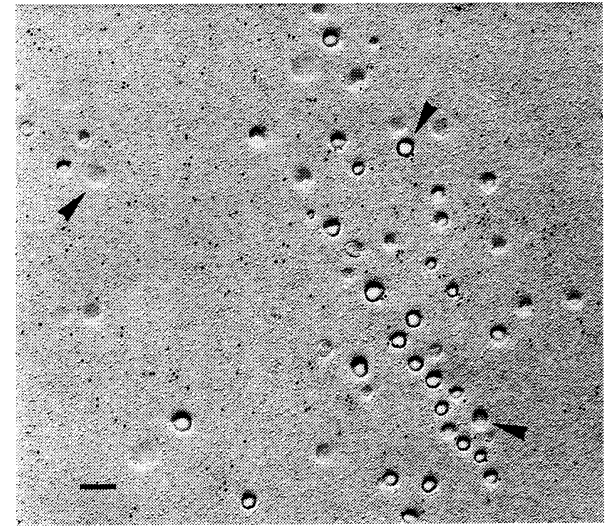

Fig. 4 Caveolae and distribution of $\mathrm{Gi} 2 \alpha$ A freeze-fracture replica of plasma membrane was labeled for immunogold electron microscopy. The labeling of Gi2 $\alpha$ is observed not only around caveolae (arrowheads), but also in other portions of the plasma membrane. Bar : $200 \mathrm{~nm}$.

法によりラフトが生きた細胞の形質膜において直 径約 $70 \mathrm{~nm}$ 以下の動的なドメインとして存在す ることが示された ${ }^{35}{ }^{36)}$. また形質膜のコレステ ロール含量を減少させるとラフトの構造が失われ ることも明らかにされた. ラフトの脂質成分はカ ベオラと共通であるが，ラフトはカべオラのよう な一定の微細構造を形成せず, 形質膜内での離合 集散を繰り返し，その大きさや形はたえず変化す ると考えられる. カベオラはラフトの一部がカベ オリンによって安定化され，陥凹構造を形成した ものと言えるかも知れない (Fig. 3). 種々のカべ オラ精製法によって得られる低密度の膜画分には ラフトとカベオラの両方が含まれており, Table 1 の分子の多くは 2 つの゙メインに共通に分布す る可能性が高い33). 従ってシグナル伝達などに 関する分子もカべオラだけに集中するのではな く，カベオラとラフトにまたがって分布すると考 えるのが妥当であろう ${ }^{37)}$ (Fig. 4).

「カベオラ画分」にラフト成分が含まれるか否 かについては研究者間に見解の相違があり, カべ オラとラフトの関係について完全なコンセンサス が得られている訳ではない. カベオリンのない界 面活性剤不溶性の膜ドメイン，すなわちラフトを 
カベオラに含めるべきだという意見もある ${ }^{38)}$. しかし, 元来, カベオラとラフトは全く独立した ドメインではなく，互いに移行し得る動的な関係 にあると推測される．例えばゴルジ装置から頂部 形質膜への輸送小胞にはラフト成分とカベオリ ン-1が含まれており ${ }^{39)}$ ，その意味では形質膜の カベオラの分子組成に非常に近いはずである。し かし, 輸送小胞が形質膜に到達すると, ラフト成 分はカベオリン-1 から離れて形質膜全域に再分 布すると考えられる. 一方, 抗体などで架橋され たラフト成分はカベオラに集合する21，22)。これ らの現象のメカニズムは明らかではなく, カべオ ラとラフトについて検討すべき課題は多く残され ている.

\section{4. カベオラと細胞内膜系}

カベオラは形質膜全体に一様に見られるのでは なく, 細胞辺縁部などにパッチを形成するなど, 偏った分布を示す. カベオラが往々にしてストレ スファイバーに沿って見られることから，分布を 規定する要因の 1 つはアクチンであると考えられ $3^{40)}$. また別の要因として，小胞体との関係が 挙げられる，骨格筋細胞での $\mathrm{T}$ 細管之筋小胞体 の関係に類似して, 非筋細胞でのカベオラと小胞 体は常に近接して見られ，小胞体の分布が変化す るとカべオラは忠実にそれに付随する ${ }^{41)}$. 両者 の間には何らかの構造的なリンクがあると考えら れ, さらに上に触れたカルシウムや次に述べるコ レステロールに関する機能的な連関も予想され る.

形質膜のコレステロール含量の多寡がカベオラ の増減と相関することから, カベオラの形成には コレステロールが重要な役割を果たすことが知ら れてきた ${ }^{42)}$. 最近の報告によると，小胞体で新 規に合成されたコレステロールは細胞質中でカべ オリン -1 , 熱ショック蛋白質, イムノフィリンと コンプレックスを形成し，ゴルジ装置を経由せず にカべオラに輸送されるという43)。また LDL として細胞内に取り込まれたコレステロールは形 質膜への輸送の後，まずカべオラに入り，過剰な
コレステロールはカベオラから細胞外の HDL に 受け渡されるらし(44).さらにコレステロール の取り込みが増加すると, カベオリン-1 の転写 活性が上昇することも報告されている ${ }^{45)}$ 。これ らの実験結果はコレステロール結合蛋白質である カベオリン-146) がコレステロールの細胞内輸送 の主役であり, カベオラが輸送の重要な中継点之 なることを示唆している. しかし，上記の実験の 定量的解析に用いられたカベオラ標品にはラフト が含まれている可能性があり，シグナル伝達と同 様, コレステロール輸送がカベオラだけの機能な のか，それともラフトも関与するのか，という点 は決着していない.

\section{5. カベオラと疾患}

癌遺伝子によってトランスフォームし，基質接 着依存性を失った細胞ではカベオリン -1 発現量 とカべオラ数がともに激減すること ${ }^{47)}$ ，これら の細胞にカベオリン-1 をトランスフェクトする と基質接着依存性が回復すること ${ }^{48)}$ が知られて いる.これらの結果は, カベオラでのシグナル伝 達が細胞増殖の制御に重要であり，その破綻が無 秩序な細胞増殖を招いたと解釈された. しかし最 近の報告では，進行した前立腺癌のうち男性ホル モン除去療法に対する感受性を失ったものではカ ベオリン-1 発現量が増加しており, アンチセン ス法で発現量を抑制すると男性ホルモン除去に対 する感受性を回復したという ${ }^{49)}$. カベオラ・カ ベオリン量の減少が細胞の脱分化や癌化に直結す るとは言えず, 発癌機構や細胞種によって異なる メカニズムが作動している可能性を考えなくては ならないのかも知れない.

このほか, 筋細胞で発現するカベオリン -3 遺 伝子の異常が肢帯型筋ジストロフィーの一部で見 られることが報告された ${ }^{50)}$ 。 また高血圧ラット ではカべオラの異常な増加が動脈の内皮細胞で認 められ, 高血圧の発症や病態との関連が注目され ている ${ }^{51)}$. カベオラが関与する現象の多様さか ら考えて, カベオラやカベオリンの異常は種々の 疾患の原因となり得ると推測される. 


\section{6. おわりに}

カベオリンの性質を中心にカベオラに関する知 見を記し，カべオラとラフトの関係について筆者 らの考えを述べた. シグナル伝達と細胞内コレス テロール輸送, さらに本稿ではとりあげなかった ポトサイトーシスという低分子取り込みのメカニ ズムはいずれも過去数年間にカべオラの機能とし て提唱されたものである. しかし上に述べたよう に前 2 者についてはラフトとの関係が十分に整理 されておらず，ポトサイトーシス仮説に対しても 有力な反論が提出されている52).これらの機能 のうち, どれが本当にカべオラ固有のものであり, どれがラフトのものであるのか, またカべオラと ラフトの関係はどのように制御されているのか. 残された問題は多いと言わざるを得ないが，今後 の研究によってこれらの問題が解決された時, 形 質膜の新たな姿が浮かび上がってくるのではない だろうか.

\section{文献}

1) Yamada E : J. Biophys. Biochem. Cytol., 1 445-457 (1955)

2) Rothberg K G, Heuser J E, Donzell W C, Ying Y S, Glenney J R, Anderson R G W : Cell, 68 673-682 (1992)

3) Scherer P E, Okamoto T, Chun M, Nishimoto I, Lodish H F, Lisanti M P : Proc. Natl. Acad. Sci. USA, 93 131-135 (1996)

4) Tang $Z$, Scherer $P$ E, Okamoto $T$, Song $K$, Chu C, Kohtz D S, Nishimoto I, Lodish H F, Lisanti M P : J. Biol. Chem., 271 2255-2261 (1996)

5) Galbiati F, Volonte D, Gil O, Zanazzi G, Salzer J L, Sargiacomo M, Scherer P E, Engelman J A, Schlegel A, Parenti M, Okamoto T, Lisanti M P : Proc. Natl. Acad. Sci. USA, 95 10257-10262 (1998)

6) Parton R G : Curr. Op. Cell Biol., 8 542-548 (1996)

7) Dietzen D J, Hastings $W$ R, Lublin D M : J. Biol. Chem., 270 6838-6842 (1995)

8) Glenney J R, Jr. : J. Biol. Chem., 264 2016320166 (1989)
膜 (MEMBRANE), Vol. 24 No. 1 (1999)

7

9) Mastick C C, Brady M J, Saltiel A R : J. Cell Biol., 129 1523-1531 (1995)

10) Vepa $S$, Scribner $W$ M, Natarajan V : Free Radic. Biol. Med., 22 25-35 (1997)

11) Monier S, Parton R G, Vogel F, Henske A, Kurzchalia T V : Mol. Biol. Cell, 6 911-927 (1995)

12) Song KS, Tang $Z$, Li S, Lisanti M P : J. Biol. Chem., 272 (7) 4398-4403 (1997)

13) Fra A M, Williamson $E$, Simons $K$, Parton $R$ G: Proc Natl Acad Sci USA, 92 8655-8659 (1995)

14) Vogel U, Sandvig K, van Deurs B : J. Cell Sci., 111 825-832 (1998)

15) Couet J, Li S, Okamoto T, Ikezu T, Lisanti M P : J. Biol. Chem., 272 6525-6533 (1997)

16) Li S, Okamoto T, Chun M, Sargiacomo M, Casanova J E, Hansen S H, Nishimoto I, Lisanti M P : J. Biol. Chem., 270 15693-15701 (1995)

17) Brown D, Rose J K : Cell, 68 533-544 (1992)

18) Sargiacomo M, Sudol M, Tang Z, Lisanti M P : J. Cell Biol., 122 789-807 (1993)

19) Fra A M, Williamson $E$, Simons $K$, Parton $R$ G : J. Biol. Chem., 269 30745-30748 (1994)

20) Gorodinsky A, Harris D A : J. Cell Biol., 129 619-627 (1995)

21) Mayor S, Rothberg K G, Maxfield F R : Science, 264 1948-1951 (1994)

22) Fujimoto $\mathrm{T}:$ J. Histochem. Cytochem., 44 929-941 (1996)

23) Schnitzer J E, McIntosh D P, Dvorak A M, Liu J, Oh P : Science, 269 1435-1439 (1995)

24) Smart E J, Ying $Y$ S, Mineo C, Anderson R G: Proc. Natl. Acad. Sci. USA, 92 1010410108 (1995)

25) Song S K, Li S, Okamoto T, Quilliam L A, Sargiacomo M, Lisanti M P : J. Biol. Chem., 271 9690-9697 (1996)

26) Stan $R V$, Roberts $W G$, Predescu $D$, Ihida $K$, Saucan L, Ghitescu L, Palade G E : Mol. Biol. Cell, 8 595-605 (1997)

27) Fujimoto T, Nakade S, Miyawaki A, Mikoshiba K, Ogawa K : J. Cell Biol., 119 15071513 (1992)

28) Schnitzer J E, Oh P, Jacobson B S, Dvorak A M : Proc. Natl. Acad. Sci. USA, 92 1759-1763 
(1995)

29) Fujimoto T : J.Cell Biol., 120 1147-1157 (1993)

30) Feron O, Belhassen L, Kobzik L, Smith T W, Kelly R A, Michel T : J. Biol. Chem., 271 22810-22814 (1996)

31) Garcia Cardena G, Oh P, Liu J, Schnitzer J E, Sessa W C : Proc. Natl. Acad. Sci. USA, 93 6448-6453 (1996)

32) Shaul P W, Smart E J, Robinson L J, German Z, Yuhanna I S, Ying Y, Anderson R G, Michel T : J. Biol. Chem., 271 6518-6522 (1996)

33) Fujimoto $\mathrm{T}$, Hagiwara $\mathrm{H}$, Aoki $\mathrm{T}$, Kogo $\mathrm{H}$, Nomura R : J. Electron Microsc., 47 451-460 (1998)

34) Simons K, Ikonen E : Nature, 387 569-572 (1998)

35) Friedrichson T, Kurzchalia T V : Nature, 394 802-805 (1998)

36) Varma R, Mayor S : Nature, 394 798-801 (1998)

37) Nomura R, Inuo $C$, Takahashi $Y$, Asano $T$, Fujimoto T : FEBS Lett., 415 139-144 (1997)

38) Anderson R G W : Annu. Rev. Biochem., 67 199-225 (1998)

39) Kurzchalia T V, Dupree P, Parton R G, Kellner R, Virta H, Lehnert M, Simons K : $J$. Cell Biol., 118 1003-1014 (1992)

40) Fujimoto T, Miyawaki A, Mikoshiba K : $J$. Cell Sci., 108 7-15 (1995)

41) Kogo H, Shioya M, Takahashi Y, Fujimoto T :
Acta Histochem. Cytochem., 30 593-599 (1997)

42) Chang W J, Rothberg K G, Kamen B A, Anderson R G W : J. Cell Biol., 118 63-69 (1992)

43) Uittenbogaard A, Ying Y, Smart E J : J. Biol. Chem., 273 6525-6532 (1998)

44) Fielding P E, Fielding C J : Biochemistry, 34 14288-14292 (1995)

45) Fielding C J, Bist A, Fielding $\mathrm{P}$ E : Proc. Natl. Acad. Sci. USA, 94 3753-3758 (1997)

46) Murata M, Peranen J, Schreiner R, Wieland F, Kurzchalia T V, Simons K : Proc. Natl. Acad. Sci. USA, 92 10339-10343 (1995)

47) Koleske A J, Baltimore D, Lisanti M P : Proc. Natl. Acad. Sci. USA, 92 1381-1385 (1995)

48) Engelman J A, Wykoff C C, Yasuhara S, Song K S, Okamoto T, Lisanti M P : J. Biol. Chem., 272 (26) 16374-16381 (1997)

49) Nasu Y, Timme T L, Yang G, Bangma C H, Li L, Ren C, Park S H, DeLeon M, Wang J, Thompson T C : Nat. Med., 4 1062-1064 (1998)

50) Minetti C, Sotgia F, Bruno C, Scartezzini P, Broda P, Bado M, Masetti E, Mazzocco M, Egeo A, Donati M A, Volonte D, Galbiati F, Cordone G, Bricarelli F D, Lisanti M P, Zara F : Nat. Genet., 18 (4) 365-368 (1998)

51) Hazama F, Ozaki T, Amano S : Stroke, 10 245-252 (1979)

52) Mayor S, Sabharanjak S, Maxfield F R : EMBO J., 17 4626-4638 (1998)

（受付 1998 年 10 月 20 日 掲載決定 10 月 26 日） 